\title{
Creating a specialized discourse: the case of the Philosophical Transactions
}

David Banks

\section{(2) OpenEdition}

1 Journals

Electronic version

URL: http://journals.openedition.org/asp/98

DOI: $10.4000 /$ asp.98

ISBN: 978-2-8218-0410-4

ISSN: 2108-6354

Publisher

Groupe d'étude et de recherche en anglais de spécialité

Printed version

Date of publication: 1 November 2009

Number of pages: $29-44$

ISSN: 1246-8185

\section{Electronic reference}

David Banks, «Creating a specialized discourse: the case of the Philosophical Transactions », ASp [Online], 56 | 2009, Online since 25 May 2012, connection on 04 November 2020. URL : http:// journals.openedition.org/asp/98; DOI : https://doi.org/10.4000/asp.98

This text was automatically generated on 4 November 2020

Tous droits réservés 


\title{
Creating a specialized discourse: the case of the Philosophical Transactions
}

\author{
David Banks
}

\section{Introduction}

1 In this paper ${ }^{1}$ I shall first discuss the virtuosi, or gentlemen scientists, and their importance for the Royal Society; I shall then consider the creation of the Philosophical Transactions and how it fitted into this situation. This will provide the background for an analysis of the contents of the Philosophical Transactions during the first year of its publication, 1665. I will show that Henry Oldenburg rapidly established a convention whereby he used verbatim material where possible, and intervened where necessary, mainly to translate from languages other than English, and to summarize items that would otherwise have been too long. Finally, on the basis of a thematic analysis of selected items, I shall hypothesize that in terms of thematic structure these items were already on the way to adopting the conventions of the scientific article of the following century.

\section{The Royal Society and the virtuosi}

2 The Royal Society was founded in 1660 and received its royal charter in 1662 (Lyons 1944, McKie 1960). However, despite the fact that it could claim royal patronage in view of its royal charter, it was never subsidized by the crown. Various kings occasionally financed specific expeditions, but the financial responsibility for its permanent running costs fell on the Society itself. Since the Royal Society had to rely on its own resources, the presence of virtuosi within its ranks was particularly important. The virtuosi were gentlemen scientists, that is, people with an active interest in science, or "natural philosophy" as it was then called, but who had private financial means such that they did not have to earn their living. The OED gives as the first (but now obsolete) definition of virtuoso: "one who has a general interest in arts and sciences, or who pursues special 
investigation in one or more of these; a learned person, a scientist, savant, or scholar". This is derived from the Italian word virtuoso, meaning "learned, skilled, skilful, full of learning". The collection of subscriptions was a constant problem until a fairly late date, but particularly in the early years. According to Lyons (1944), by the end of 1663 , unpaid subscriptions amounted to $£ 158$, and by 1676 this had risen to $£ 2,000$. Sorrenson points out that:

The Society, bereft of any regular state support, could not have carried out its main functions [...] without the subscriptions of all its Fellows [...] men of high social status joined easily, those of middling status less so, and those of low social class not at all. (Sorrenson 1996: 33)

Consequently, electing rich members, even if they were not distinguished scientists, was vital to the Royal Society's continued existence. This can be contrasted with the situation in the French Académie Royale des Sciences, founded in 1666, which was created as a royal institution; it was funded by the monarchy, its members were remunerated (i.e., received a pension), and thus it faced none of the financial difficulties that confronted the Royal Society. On the other hand, the Académie was subject to royal control (McClellan 2001, Gross et al. 2002).

So the virtuoso was a gentleman, financially independent, who was interested in scientific activities. The notion of scientific interests is here very wide, and includes curious facts and events, and the unsystematic collection of specimens of all sorts (Gotti 2006). Atkinson describes him as:

[...] the gentleman virtuoso, the financially worry-free individual who cultivated various socially approved pastimes as ways of occupying and improving himself. (Atkinson 1999: 17)

The fact that he was an amateur, in the sense that he did not carry out his pursuits for a living, did not prevent some virtuosi from being excellent scientists. Boyle is an obvious example. As son of the Earl of Cork, he was totally free of any financial worries, but he was also one of the foremost scientists of his day (Gotti 1996).

In this early period, we might include among those who were not virtuosi, men like Hooke, Oldenburg and Papin, who all did have to earn their living. Atkinson (1999) gives these men marginal gentlemanly status. Nevertheless, not having to work for financial reasons could be seen as a scientific virtue, perhaps making virtue out of necessity:

[...] the early empiricists portrayed themselves as freely pursuing the study of divinely created nature, unfettered by philosophical predispositions, or the need to support themselves as professional scholars. (Atkinson 1999: 149)

In Table 1, which is based on Sorrenson (1996), it can be seen that for each of the two periods considered, in the late seventeenth and in the mid-eighteenth centuries, at least $50 \%$ of the Royal Society's members belonged to what might be called the leisured classes of the time.

Table 1. Percentage of members of the Royal Society in different social groups

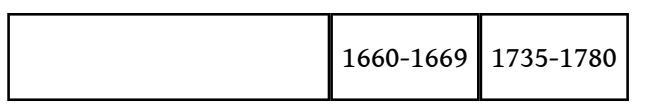




\begin{tabular}{|l|c|c|}
\hline Aristocrat & $14 \%$ & $20 \%$ \\
Courtier/civil servant & $20 \%$ & $15 \%$ \\
Gentleman & $15 \%$ & $5 \%$ \\
Lawyer & $4 \%$ & $5 \%$ \\
Doctor/apothecary & $16 \%$ & $25 \%$ \\
Clergy/academic writer & $20 \%$ & $16 \%$ \\
Merchant & $7 \%$ & - \\
Other & $3 \%$ & $3 \%$ \\
\hline
\end{tabular}

8 In these circumstances in was probably inevitable that the Royal Society should function as a gentlemen's club. This situation was to have far-reaching consequences, for what Atkinson calls this "genteel and amateur scientific community" was to continue "in a gradually weakening form up to and beyond the age of Darwin", and its influence stretched into the twentieth century (Atkinson 1999: 28).

\section{The Philosophical Transactions}

Understanding the social situation of the virtuosi is important in understanding the role of the Philosophical Transactions, for they were the public it was mainly intended to cater for.

10 Although the Philosophical Transactions had the imprimatur of the Royal Society, it was founded by Henry Oldenburg as a private enterprise. As was pointed out above, Oldenburg did not belong to the leisured classes, and hence had to work to make ends meet. He thought of the Philosophical Transactions as a way of providing himself with additional income. He had become the hub of a network of scientific correspondence (Hall 2002, Bluhm 1960). At that time, there were basically two ways of disseminating scientific knowledge; one was books, the other was correspondence. Letters were indeed a recognized way of spreading information. Although letters were sent by one individual to another, it was understood that they could be copied, sent on, read to learned societies, and so on. Even claims of priority could be based on what had been written in a letter. Hence, Oldenburg's decision to use printing as a way of improving the distribution of the knowledge, or "intelligence" as he called it, which he received by letter, can be seen as a fairly natural extension of the existing situation. But, of course, he hoped to make a profit out of it into the bargain.

11 The first issue appeared on 6 March 1665, only two months after the first issue of the Journal des Sçavans (Morgan 1928). Unlike the Mémoires of the Académie Royale des Sciences, which were restricted to the members of the Académie, and were not in fact published until the next century, the Philosophical Transactions was open to everyone, including, as Gross et al. point out, "seafarers, physicians, world travellers, European savants, and the like" (2002: 67).

One of the less well-known facts is that Oldenburg originally intended to produce a Latin edition (Bluhm 1960), and Johns claims that:

From the very start of the enterprise, Oldenburg had envisaged that there would be

a three-monthly Latin version. And since it would reach a far wider audience than 
the English, this Latin work could properly be considered its more important

branch. (Johns 2000: 171) It contained an introduction, nine news items and an obituary of the mathematician Fermat. The whole issue was written by Oldenburg himself, the news items being based on the information he had received in his correspondence.

The second issue appeared on 3 April 1665, and was the first issue to contain illustrations (Banks forthcoming). It contained six items including a review of Hooke's Micrographia. Four of the items are specifically stated to be extracts from letters. Two of these had been sent directly to Oldenburg by correspondents in Rome and Paris. One had been sent by Pope, then in Venice, to Wilkins, and is headed:

Extract of a Letter, lately written from Venice by the Learned Doctor Walter Pope, to the Reverend Dean of Rippon, Doctor John Wilkins, concerning the Mines of Mercury in Friuli; and a way of producing Wind by the fall of Water. (Philosophical Transactions 3 April 1665)

The fourth extract is from a letter sent by Digges to Palmer, and bears the heading:

An extract of a Letter, containing some Observations made in the ordering of Silk-worms, communicated by that known Vertuoso, Mr. Dudley Palmer, from the ingenuous Mr. Edward Digges. (Philosophical Transactions 3 April 1665) their initial recipients, Wilkins and Palmer. In the case of the letter from Digges to Palmer, it is possible that the phrase "communicated by" implies that the letter had been read at a meeting of the Royal Society. The final item in the 3 April issue is said to be an "observation" headed: 
An observation imparted to the Noble Mr Boyle, by Mr. David Thomas, touching some particulars further considerable in the Monster mentioned in the first Papers of these Philosophical Transactions. (Philosophical Transactions 3 April 1665) heading, 1665) 1665)

SIR,

This, then, has been supplied by Boyle, from information given by Thomas. However, whether this information was "imparted" orally or in writing is not clear from the entry. Thus five of the six entries in this issue incorporate verbatim extracts, the only exception being the book review.

The issue for 8 May contains seven items. One is a summary of a book by Boyle which has not yet been published but which is in press. Four of the items are papers which had been read to the Royal Society. Each of these has an introduction by Oldenburg, and one has, in addition, a closing comment by him too. Thus the article which has the

Of the Way of killing Ratle-snakes. (Philosophical Transactions 8 May 1665)

has the following introduction by oldenburg:

There being not long since occasion given at a meeting of the Royal Society to discourse of Ratle Snakes, that worthy and inquisitive Gentleman, Captain Silas Taylor, related the manner, how they were killed in Virginia, which he afterwards was pleased to give in writing, attested by two credible persons in whose presence it was done, which is, as follows. (Philosophical Transactions 8 May 1665)

And that which has the heading,

A Relation of Persons killed with Subterraneous Damps. (Philosophical Transactions 8 May

has the following introduction by Oldenburg:

This Relation was likewise made to the Royal Society, by that Eminent Virtuoso Sir R. Moray, who was pleased, upon their desire, to give it them in writing, as followeth. (Philosophical Transactions 8 May 1665)

as well as the following closing comment:

This story of Sir R. Moray affirmed to have received from the Earle of Weymes, Brother in Law to the Lord Sinclair, as it was written from Scotland. (Philosophical Transactions 8 May

The other two items in this issue are summaries of books, one by the French scientist Auzout, the other by Boyle. These are penned by Oldenburg himself. This issue, then, seems to present a mixture of the strategies he had adopted in the first two issues: some items he writes up himself, while others are printed verbatim.

The issue for 5 June 1665 has eight items, one of which is a paper by Moray, printed verbatim and without introduction. The remaining seven items all relate to a book by the French scientist, Auzout. There is a review of the book, and five summaries, written by Oldenburg, of sections of the book. The other item is a letter from Hooke on the same subject, and is an answer to a point raised by Auzout in the book. This letter is printed verbatim, with the salutation but without the valediction. It is headed

Mr. Hook's Answer to Monsieur Auzout's Considerations, in a Letter to the Publisher of these

Transactions. (Philosophical Transactions 5 June 1665)

and begins as follows:

Together with my most hearty thanks for the favour you were pleased to do me, in sending me an Epitome of what had been by the ingenious Monsieur Auzout animadverted on a description, I had made of an engine for grinding Spherical Glasses, I thought my self 
obliged, both for your satisfaction, and my own Vindication, to return to you my present

thoughts upon those Objections. (Philosophical Transactions 5 June 1665)

The Philosophical Transactions was indeed revived after a three-month break, and the
next issue appeared on 6 November 1665. Oldenburg had always had problems with
printers (or "stationers" as they were then called), but these were much increased by
the plague since most printers, like many others, had left the capital. It is a sign of
oldenburg's industry that he was able to get the Philosophical Transactions back on its
feet so quickly (Johns 2000). The first item in this issue is headed

The Philosophical Transactions was indeed revived after a three-month break, and the
next issue appeared on 6 November 1665. Oldenburg had always had problems with
printers (or "stationers" as they were then called), but these were much increased by
the plague since most printers, like many others, had left the capital. It is a sign of
oldenburg's industry that he was able to get the Philosophical Transactions back on its
feet so quickly (Johns 2000). The first item in this issue is headed

The Philosophical Transactions was indeed revived after a three-month break, and the
next issue appeared on 6 November 1665. Oldenburg had always had problems with
printers (or "stationers" as they were then called), but these were much increased by
the plague since most printers, like many others, had left the capital. It is a sign of
oldenburg's industry that he was able to get the Philosophical Transactions back on its
feet so quickly (Johns 2000). The first item in this issue is headed

The Philosophical Transactions was indeed revived after a three-month break, and the
next issue appeared on 6 November 1665. Oldenburg had always had problems with
printers (or "stationers" as they were then called), but these were much increased by
the plague since most printers, like many others, had left the capital. It is a sign of
oldenburg's industry that he was able to get the Philosophical Transactions back on its
feet so quickly (Johns 2000). The first item in this issue is headed

The Philosophical Transactions was indeed revived after a three-month break, and the
next issue appeared on 6 November 1665. Oldenburg had always had problems with
printers (or "stationers" as they were then called), but these were much increased by
the plague since most printers, like many others, had left the capital. It is a sign of
Oldenburg's industry that he was able to get the Philosophical Transactions back on its
feet so quickly (Johns 2000). The first item in this issue is headed

An Account of a not ordinary Burning Concave, lately made at Lyons, and compared with several others made formerly. (Philosophical Transactions 6 November 1665)

This reminds us of the practical difficulties which surrounded the production of these early issues of the Philosophical Transactions, and not least among them was the fact that 1665 was the year in which the plague reached London. It can be noted that oldenburg stayed on in London, when most of the members of the Royal Society had fled to the relative safety of the countryside. 
but the introduction tells us about the revival of the journal:

An opportunity being presented to revive the publishing of these Papers, which for some Moneths hath been discontinued by reason of the great Mortality in London, where they were begun to be printed; it hath been thought fit to embrace the same, and to make use thereof for the gratifying of the Curious, that have been pleased to think well of such Communications: [...] (Philosophical Transactions 6 November 1665)

This issue contains ten items, five of them written by oldenburg, and five at least partially verbatim. The items written by Oldenburg are translations of two letters, one in Latin, the other in French, with an introduction by Oldenburg, a summary of a book published in French, with an introduction by Oldenburg, a translated extract from the same book, a summary of a book by Hevelius published in Latin, with the translation of a letter from Auzout to Petit on the same subject, and a summary of a book by Athanasius Kircher, published in Latin. The five items that are partially verbatim are in fact accompanied by an introduction by Oldenburg. These are a letter from Hevelius, a letter from Evelyn, who was then in Paris, a letter from Boyle, transmitting information received from Clark and Lower, a letter of which it is said "the same Searcher of Nature, that was alleged in the immediate precedent Observations, did impart also the following, in another letter from Oxford", so this is presumably Boyle again, and finally what must be one of the first "stop press" items in the history of English, again from Boyle with introduction by Oldenburg. This is headed

A farther account of an Observation above-mentioned about White Blood. (Philosophical

Transactions 6 November 1665) and begins:

Since the Printing of the former Sheet, there is this farther account from the same hand (Philosophical Transactions 6 November 1665)

Evidently Oldenburg thought it important to get this short piece in, even though printing of the issue was already underway.

In this issue the strategies being used by Oldenburg seem to be crystallizing into two forms: where the language used is English, the item is printed verbatim with an introduction supplied by Oldenburg, but where the item is in some other language, and so translation is necessary, the whole item is written by oldenburg.

The final issue of the year 1665, which came out on 4 December 1665, has seven items. Two of these have verbatim material with an introduction by Oldenburg, and both come from Auzout. One of these has the heading

Monsieur Auzout's Speculations of the Changes, likely to be discovered in the Earth and Moon, by their respective Inhabitants. (Philosophical Transactions 4 December 1665)

and this begins in the following way:

This Inquisitive Philosopher in a letter of his, lately writen to his correspondent in London, takes occasion to discourse of his considerations concerning those Changes mentioned in the Title, as followes;

I have (saith he) sometimes thought [...] (Philosophical Transactions 4 December 1665)

"I have ... sometimes thought" is the beginning of the verbatim section, with the interpolation of "saith he". The other items in this issue are a personal eye-witness account by Oldenburg, a summary of an extract from a book published in Latin, a short news item, only seven lines long, a summary of a letter from Germany (perhaps written in German, though he does not specifically say so), and a review of a book printed abroad ("printed beyond the Seas") on intravenous injections, but which appears to be 
basically a priority claim for Wren, who had already carried out this kind of experiment.

Hence we can say that by the end of 1665 , Oldenburg is using verbatim material where this is possible, usually supplying an introduction. On the other hand, where the information is in some other language and translation is therefore necessary, or where the item is too long and has to be summarized, then we get an item which has been completely written (or rewritten) by oldenburg.

\subsection{Ten years later}

I would now like to fast forward ten years to 1675 . Ten years is not simply a convenient round figure; Oldenburg was to die in 1677, so 1675 is fairly close to the end of his life. Subsequently, Nehemiah Grew continued the Philosophical Transactions into 1678, but then Robert Hooke took over. There had been a great deal of animosity between oldenburg and Hooke, and the latter disbanded the Philosophical Transactions and replaced it with his own Philosophical Collections. The Philosophical Collections was published from 1679 to 1682, but never had the same success as the Philosophical Transactions. In 1683 the Philosophical Transactions was revived under Robert Plot, and has continued to the present day (Lyons 1944). However, Oldenburg was still in charge in 1675, and the issue for 25 March 1675 contains seven items. Two of these are book reviews, two are items translated by oldenburg from the Journal des Sçavans; in addition there is a summary of a book by Picard, a letter which is printed verbatim, without introduction, with its salutation but without the valediction, and a verbatim extract from a letter in Latin, actually printed in Latin, not translated. If this issue is representative of what Oldenburg was doing in 1675 , then it seems that he was still following the strategies that he had developed by the end of 1665 . The exceptional item here is, of course, the item printed in Latin. Perhaps this was simply lack of time, or perhaps at the age of 60 he was getting understandably tired.

\section{Thematic Structure}

It would now be interesting to consider at least one of the linguistic features that result from the choices being made in the construction of this discourse; and if one feature is to be singled out rather than another, it must be thematic structure. It has been argued that thematic structure is the driving force behind scientific writing (Halliday 1988, 2004b, Halliday \& Martin 1993, Banks 2008a, 2008b). Many of the features commonly associated with scientific writing, such as use of the passive voice, in fact, derive from choices in thematic structure. In previous works I analyzed the thematic structure of a sample of articles from the Philosophical Transactions covering the period 1700 to 1980 (Banks 2008a, 2008b). I would now like to look at the thematic structure of four articles selected from the issues discussed above. These have been selected in an attempt to cover the basic types of item found in those issues, that is, a letter printed verbatim, a verbatim letter with an introduction by Oldenburg, a summary of a book, and the writeup of a paper presented at the Royal Academy. This is obviously a tiny sample, and requires all the reserve appropriate to a mini-corpus (Banks 2005b), but as I argued in Banks 2008a, insofar as the results derived from a mini-corpus provide a coherent picture, on the basis of an analogy with normal science (Kuhn 1970), those results can 
be taken as valid until shown to be otherwise. Thematic structure operates at the level of clause, and is analyzed in terms of Theme and Rheme, ${ }^{2}$ where Theme is defined as the speaker's starting point, and is realized in English as initial position in the clause (Halliday 2004a, Banks 2005a). I previously identified 14 semantic categories for topical Theme, and have attempted to apply these to the selected articles. The 14 categories are Themes which refer to:
1. the object of study (Obj)
2. the experiment (Exp)
3. the equipment (Equip)
4. observation (Obs)
5. the author (Auth)
6. humans other than the author (Oth)
7. other parts of the same text (Meta)
8. other texts (Inter)
9. existential clauses (Exist)
10. the field of study (Field)
11. mental processes and argumentation (Ment)
12. time (Time)
13. radical modality (Rad)
14. mathematical expressions (Math)

The first article I shall look at is "Mr. Hook's Answer to Monsieur Auzout's Considerations, in a Letter to the Publisher of these Transactions". This item deals with the grinding of lenses and their use in telescopes, and is a reply to Auzout's criticisms of Hooke. It appeared in the issue for 5 June 1665. It has a total of 67 ranking clauses and the topical Themes are distributed as shown in Table 2.

Table 2. Topical Themes in “Mr Hook's Answer..." (5 June 1665)

\begin{tabular}{|l|l|l|}
\hline Exp & 19 & $28 \%$ \\
\hline Equip & 11 & $16 \%$ \\
\hline Auth & 12 & $18 \%$ \\
\hline Oth & 2 & $3 \%$ \\
\hline Inter & 2 & $3 \%$ \\
\hline Ment & 20 & $30 \%$ \\
\hline Rad & 1 & $1 \%$ \\
\hline Total & 67 & \\
\hline
\end{tabular}

This item is technological rather than experimental, and here experimental Themes should be taken in a broad sense so that it includes manipulation of the equipment to 
produce the desired results. The following is an example (the topical Theme is printed in bold):

The giving the Inclination to the Mandrils, is not at all difficult. (Philosophical Transactions 5 June 1665)

Nineteen (28\%) of the topical Themes are of this type. References to the equipment account for a further 11 (16\%). The following is an example of this type:

For, as to the possibility of getting Plates of Glass thick and broad enough without veins, I think that not now so difficult here in England, where I believe is made as good, if not much better Glass for Optical Experiments, than ever I saw come from Venice. (Philosophical Transactions 5 June 1665)

51 The human category is mainly references to the author (Hooke), which is not surprising, given that he is defending his own position; this accounts for $12(18 \%)$ of the Themes. The following is an example:

For, I had made trials, as many as my leisure would permit, not without some good success;

[...] (Philosophical Transactions 5 June 1665)

52 The other major category here is that of mental/argumentation Themes. These account for $20(30 \%)$. The fact that Hooke is arguing his case leads to him thematizing the argument itself. The following is an example:

For his Proposal of amendments of some inconveniences in this way, I return him my thanks; [...] (Philosophical Transactions 5 June 1665)

In Banks 2008a I found that what I called the study or experimental group of Themes, that is Obj+Exp+Equip+Obs, ranged between $50 \%$ and $90 \%$ for articles published during the eighteenth century, and the percentage for the human group, that is Auth+Oth, ranged from $10 \%$ to $25 \%$. It can be seen that this article published 35 years before the beginning of the eighteenth century is within the range for the human group, with $21 \%$, but fairly low for the study group, at $44 \%$. This is compensated for however by the mental/argumentation category, brought about by the defensive argumentative nature of the item.

The second item I shall consider is "An Advertisement of a way of making more lively Counterfeits of Nature in Wax, then are extant in Painting: And of a new kind of Maps in a low Relievo. Both practised in France". This item, from the 6 November issue, is a letter from Evelyn, preceded by a two-line introduction by oldenburg. It has seven ranking clauses, and only four of the categories are represented. These are shown in Table 3.

Table 3. Topical Themes in "An Advertisement of a way ..." (6 November1665)

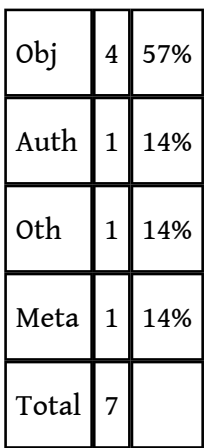



certain Stone, found in the Indies, in the head of a Serpent". This is a summary of a book published in French, with an introduction by Oldenburg. However the introduction is longer than the summary itself. The introduction takes up 20 lines, but the summary only 15 . The whole item has 12 ranking clauses, and the distribution of the topical Themes is given is Table 4.

Table 4. Topical themes in "Of the nature of a certain Stone ..." (6 November 1665)

The small number of clauses involved means that these figures must be treated with caution, but one can nevertheless note that more that half of the admittedly small number are in the object of study category.

The third item I shall consider, also from the 6 November issue, is "Of the nature of a

\begin{tabular}{|l|l|l|}
\hline Obj & 2 & $17 \%$ \\
\hline Exp & 3 & $25 \%$ \\
\hline Oth & 1 & $8 \%$ \\
\hline Inter & 3 & $25 \%$ \\
\hline Exist & 1 & $8 \%$ \\
\hline \hline Time & 1 & $8 \%$ \\
\hline \hline Sit & 1 & $8 \%$ \\
\hline Total & 12 & \\
\hline
\end{tabular}

In this article, there was one example which did not fit into the categories previously identified, and I thus created the new category of situation (Sit), to account for this. The example in question (which includes an illegible word in my copy) is:

In the East Indies and in the Kingdom of [illegible] in China, there is found a Stone in the Head of a certain Serpent (which they call by a name signifying Hairy Serpent) which heals the bitings of the same Serpent, that else would kill in 24 hours. (Philosophical Transactions 6 November 1665)

This item has 12 ranking clauses, so once again the small number means that the figures can only have indicative value. Nevertheless, it can be noted that the study group here accounts for $42 \%$, a similar figure to that for the first article considered above. The other significant category is that of references to other texts, which seems reasonable given that this is a summary of a book, and indeed two of the three Themes in question relate to the work being summarized.

Finally, I should like to consider an item from the issue for 3 July, entitled "An Account, how Adits \& Mines are wrought at Liege without Air-shafts, communicated by Sir Robert Moray". This is the written version of a paper read to the Royal Society. It has 21 ranking clauses which are distributed as in Table 5. 
Table 5. Topical Themes in "An Account how Adits and Mines ..." (3 July 1665)

\begin{tabular}{|l|l|l|}
\hline Obj & 18 & $86 \%$ \\
\hline Meta & 2 & $10 \%$ \\
\hline \hline Rad & 1 & $5 \%$ \\
\hline Total & 21 & \\
\hline
\end{tabular}

It is here obvious that the object of study accounts for the overwhelming proportion of the Themes.

61 If we now compare the ranges for the study group (Obj+Exp+Equip+Obs), the human group (Auth+Oth) and the text group (Meta+Inter), in these four articles and in the eighteenth century articles studied in Banks 2008a, we find the results given in Table 6 . These particular comparisons are significant in that they show to what extent the interest of these writers, in terms of clausal starting point (that is, Theme), is in terms of the object or phenomenon being studied rather than the scientist who is carrying out the study, or even the documents being written about it.

Table 6. Comparison of ranges for 1665 and $18^{\text {th }}$ century

\begin{tabular}{|c|c|c|}
\hline & 1665 & $18^{\text {th }}$ cent \\
\hline \hline Study group & $42 \%-86 \%$ & $50 \%-90 \%$ \\
\hline \hline Human group & $8 \%-28 \%$ & $7 \%-25 \%$ \\
\hline \hline Textual group & $0 \%-25 \%$ & $0 \%-20 \%$ \\
\hline
\end{tabular}

It can be seen that the ranges for the human group and the textual group are easily comparable. In the case of the study group, the range for 1665 is slightly lower than that for the eighteenth century, but the difference is not great. From this I think it may be reasonably hypothesized that the conventions established in the Philosophical Transactions in 1665 were already well on the way to conforming to the norms of the eighteenth century scientific articles which would be printed in that journal in the following century.

\section{Closing Comments}

We have seen that from its beginnings as a newsletter based on the correspondence received by Oldenburg, the Philosophical Transactions rapidly established itself as a significant contribution to the dissemination of knowledge in the late seventeenth century. By the end of the first year of publication, Oldenburg had established a norm whereby letters or extracts from letters written in English were printed verbatim, with, at most, an introduction which he wrote himself; items which he wrote completely were those which had to be translated from other languages, or which were otherwise 
too long, such as books, of which he supplied summaries or reviews. He was still following this pattern ten years later, when he was nearing the end of this life. An analysis of the thematic structure of a selected sample of these items shows that the thematic choices being made were similar to those established in the course of the following century. Thus the contents of the early issues of the Philosophical Transactions set up norms which were to develop into those of the eighteenth century scientific article. We can then see the significance of Oldenburg's contribution: what he did was to establish the seedbed from which the later scientific article was to develop.

I would like to thank two anonymous referees for their helpful comments.

\section{BIBLIOGRAPHY}

Atkinson, Dwight. 1999. Scientific Discourse in Sociohistorical Context, The Philosophical Transactions of the Royal Society of London, 1675-1975. Mahwah, NJ: Lawrence Erlbaum.

Banks, David. 2005a. Introduction à la linguistique systémique fonctionnelle de l'anglais. Paris: L'Harmattan.

Banks, David. 2005b. "The case of Perrin and Thomson: An example of the use of a mini-corpus". English for Specific Purposes 24/2, 201-211.

Banks, David. 2008a. The Development of Scientific Writing, Linguistic features and historical context. London: Equinox.

Banks, David. 2008b. "The significance of thematic structure in the scientific journal article, 1700-1980". In Nørgard, Nina (ed.), Systemic Functional Linguistics in Use, Odense Working Papers in Language and Communications, 29 <http://www.sdu.dk/ /media/Files/Om_SDU/Institutter/ISK/ Forkningspublikationer/OWPLC/Nr29/David\%>.

Banks, David. 2009. "Starting science in the vernacular. Notes on some early issues of the Philosophical Transactions and the Journal des Sçavans, 1665-1700”. ASp 55, 5-22.

Banks, David. Forthcoming. "Les premières images de la revue scientifique : les Philosophical Transactions, 1665-1670". In Banks, David (ed.), L'image dans le texte scientifique. Paris:

L'Harmattan.

Bazerman, Charles. 1988. Shaping Written Knowledge. The genre and activity of the experimental article in science. Madison: University of Wisconsin Press.

Bluhm, R.K. 1960. “Henry Oldenburg, F.R.S. (c.1615-1677)”. In Hartley, Harold (ed.), The Royal Society. Its origins and founders. London: The Royal Society, 182-197.

Gotti, Maurizio. 1996. Robert Boyle and the Language of Science. Milan: Guerini.

Gotti, Maurizio. 2006. "Disseminating early modern science: specialized news discourse in the Philosophical Transactions”. In Brownlees, Nicholas (ed.), News Discourse in Early Modern Britain. Bern: Peter Lang, 41-70.

Gross, Alan G., Joseph E. Harmon and Michael Reidy. 2002. Communicating Science, The scientific article from the $17^{\text {th }}$ century to the present. Oxford: Oxford University Press. 
Hall, Marie Boas. 2002. Henry Oldenburg. Shaping the Royal Society. Oxford: Oxford University Press.

Halliday, M.A.K. 1988. "On the language of physical science”. In Ghadessy, Mohsen (ed.), Registers of Written English, Situational factors and linguistic features. London: Pinter, 162-178.

Halliday, M.A.K. (revised Christian M.I.M. Matthiessen). 2004a. An Introduction to Functional Grammar, $3^{\text {rd }}$ edn. London: Arnold.

Halliday, M.A.K. (ed. Jonathan J. Webster). 2004b. The Language of Science (Collected works of M.A.K. Halliday Vol. 5). London: Continuum.

Halliday, M.A.K. and J.R. Martin. 1993. Writing Science, Literacy and discursive power. London: Falmer Press.

Johns, Adrian. 2000. "Miscellaneous methods: authors, societies and journals in early modern England". British Journal for the History of Science 33/2, 159-186.

Kronick, David A. 1962. A History of Scientific and Technical Periodicals. The origins and development of the scientific and technological press, 1665-1790. New York: Scarecrow Press.

Kuhn, Thomas S. 1970. The Structure of Scientific Revolutions, $2^{\text {nd }}$ edn. Chicago: University of Chicago Press.

Lyons, Henry. 1944. The Royal Society 1660-1940. A history of its administration under its charters. Cambridge: Cambridge University Press.

McClellan, James E. III. 2001. “The Mémoires of the Académie Royale des Sciences, 1699-1790: A statistical overview". In Halleux, Robert, James McClellan, Daniela Beraru and Geneviève Xhayet (eds.), Les publications de l'Académie Royale des Sciences de Paris (1666-1793), Vol 2. Turnhout: Brepols, 7-36.

McKie, Douglas. 1960. "The origins and foundation of the Royal Society of London". In Hartley, Harold (ed.), The Royal Society. Its origins and founders. London: The Royal Society, 1-37.

Morgan, Betty Trebelle. 1928. Histoire du Journal des Sçavans depuis 1665 jusqu'en 1701. Paris: Presses Universitaires de France.

OED (2005), CD-ROM Version 3.1, Oxford, Oxford University Press.

Sorrenson, Richard. 1996. "Towards a history of the Royal Society in the eighteenth century", Notes and Records of the Royal Society of London 50/1, 29-46.

\section{NOTES}

1. An earlier version of this paper was given at the $30^{e}$ Colloque du GERAS, Universite de Rennes 1 , 12-14 March 2009.

2. I am following the convention of Systemic Functional Linguistics where names of functions are capitalized, here Theme and Rheme. 


\section{ABSTRACTS}

The Royal Society was founded in 1660 and was made up largely of virtuosi. The Royal Society depended on their subscriptions for survival. Although the Philosophical Transactions had the imprimatur of the Royal Society, it was a private venture of Henry Oldenburg, one of the Royal Society's secretaries. The venture was conceived of as a way of making money. The Philosophical Transactions first appeared in 1665, and by the end of the first year most entries were verbatim extracts of letters, with introductions by Oldenburg; he intervened more extensively only when necessary, such as when translation was needed, or to summarize longer items such as books. Ten years later, he seemed to be using the same strategies that he had established by the end of 1665. An analysis of the thematic structure of these documents shows that they are moving towards the experimental style of the eighteenth century.

La Royal Society a été créée en 1660 ; elle était constituée principalement de virtuosi. L'existence même de la Royal Society dépendait de leurs cotisations. Bien que les Philosophical Transactions eussent l'agrément de la Royal Society, elles résultaient de l'initiative privée de Henry Oldenburg, l'un des secrétaires de la Royal Society; son entreprise était conçue comme une source de revenus. Les Philosophical Transactions ont été publiées pour la première fois en 1665 et, avant la fin de la même année, la majorité des contributions était composée d'extraits de lettres accompagnés d'introduction par H. Oldenburg. Il n'intervenait davantage que quand cela était nécessaire, par exemple quand il fallait traduire ou quand il fallait résumer des textes plus longs, tels les livres. Il semblerait que dix ans plus tard il utilisait toujours les stratégies qu'il avait établies avant la fin de 1665. Une analyse de la structure thématique de ces documents démontre qu'ils évoluaient vers le style scientifique du dix-huitième siècle.

\section{INDEX}

Mots-clés: XVIIe siècle, Oldenburg (Henry), Philosophical Transactions, Royal Society, structure thématique, texte scientifique, virtuosi

Keywords: Oldenburg (Henry), Philosophical Transactions, Royal Society, scientific text, 17th century, thematic structure, virtuosi

\section{AUTHOR}

\section{DAVID BANKS}

David Banks is Professor of English Linguistics at the Universite de Bretagne Occidentale. He is Director of ERLA (Équipe de Recherche en Linguistique Appliquée, a component of EA 4249 (HCTI), and chairman of the Association Française de la Linguistique Systémique Fonctionnelle. He has written or edited a dozen books and over fifty academic articles. His most recent publication is The Development of Scientific Writing, Linguistic Features and Historical Context (London: Equinox, 2008). David.Banks@univ-brest.fr 